\title{
COMPLEXATION STUDY OF HEAVY METAL ION CU(II) WITH AMINO ACIDS BEFORE ELIMINATION BY ULTRAFILTRATION
}

\author{
H. Rayah ${ }^{1, \bowtie}$, B. Absar ${ }^{2}$, M. R. Ghezzar ${ }^{1}$ and F. Abed ${ }^{1}$ \\ ${ }^{1}$ Laboratoire des Sciences et Techniques de l'Environnement et de la Valorisation, Faculty of \\ Sciences and Technology, University of Abdelhamid Ibn Badis- Mostaganem, BP 188, \\ Mostaganem, Algeria \\ ${ }^{2}$ Faculty of Computer Science and Exact Sciences, University of Mostaganem, \\ Chemin des crêtes, Mostaganem 27000, Algeria \\ Corresponding Author: houarirayah@gmail.com
}

\begin{abstract}
Nowadays one of the most critical issues for human life is the protection of the drinking water from contamination by heavy metals. They are toxic pollutants, which can be very dangerous for human health and the environment when they are present at high concentrations. The removal of these heavy metal ions from water has become a more than necessary issue. Ultrafiltration is considered a suitable molecular filter for the separation of big molecules, but it is still inefficient for the separation of free ions due to their weak sizes. Consequently, other methods including complexation reactions with organic ligands to trap the ions and to retain them by the membrane are considered. This work deals with the removal of toxic metallic ions by a combined complexation and -ultrafiltration process using Copper (II) ions and, amino acids as complexing agents. The complexation has been exhaustively studied by UV/visible absorbance spectrophotometry and Conductometric. The thermodynamic parameters $\left(\Delta H^{\circ}, \Delta G^{\circ}\right.$ and $\left.\Delta S^{\circ}\right)$ were derived and discussed for a complete description of the systems in solution and to demonstrate the importance of amino acids for trapping the metal cations by complexation processes.
\end{abstract}

Keywords: Amino Acids, Copper (II), Complexation, Ultrafiltration, UV-Visible Spectrophotometry, Conductometric, Thermodynamics.

RASĀYAN J. Chem., Vol. 14, No.3, 2021

\section{INTRODUCTION}

Much industrial wastewaters produced by metal finishing chemicals, automotive industry, battery, aerospace, plating chemistry, mining, and general chemical processes industries, often contain heavy metals. ${ }^{1}$ Traditional method for the elimination of these heavy metals is adsorption, ion exchange, chemical precipitation, membrane filtration, evaporation, liquid-liquid extraction, electrodeposition, crystallization, and electrochemical treatment. ${ }^{2}$ However, membrane methods and ultrafiltration (UF) in particular have been described as one of the most innovative techniques in recent years in the treatment of wastewater laden with heavy metals. These membrane separation processes reflect efficiency and economic benefits with the most developed high selectivity. ${ }^{3}$

Complexation-ultrafiltration is also a promising new technique for the removal of heavy metals toxic from liquid effluents. The use of the complexing agent in combination with UF is obligatory for the elimination of heavy metals. ${ }^{4}$ In this work, we will present, through typical examples, the role of amino acids in the environmental and biological processes, as well as the development of therapeutic chelating in case of poisoning by toxic metals. ${ }^{5-9}$

Various techniques are used to determine free metal ion concentrations in the solution. In this work, we are particularly interested in the complexation of Copper (II) with ten different amino acids. The present study will be divided into two parts: The first one concern-an experimental spectroscopy investigation on the patterns of the amino acid compared to Copper (II) in the water at a temperature of $298 \mathrm{~K}$. The spectroscopic physical quantities were established using the Benesi-Hildebrand equation, such as the association constant $\left(K^{A D}\right)$ and the molar extinction coefficients $\left(\varepsilon^{A D}\right)$ of each complex. Moreover, 
RASĀYAN J. Chem.

Vol. 14 | No. 3 |1573-1580| July - September | 2021

the energy absorption $\left(E^{C T}\right)$, and the ionization potentials of the complexes $\left(I^{D}\right)$, were determined. ${ }^{10-16}$

The second part of the work deals with the study of the behavior of the various complexes by conductometry at infinite dilution in water. The molar conductivity ( $\Lambda)$ and molar conductivity at infinite dilution $\left(\Lambda_{0}\right)$ for the ten complexes in water was measured at a temperature of $298 \mathrm{~K}$. The thermodynamic quantities including the standards Gibbs free energy $\left(\Delta G^{\circ}\right)$, the Enthalpy $\left(\Delta H^{\circ}\right)$ and the Entropy $\left(\Delta S^{\circ}\right)$ for the process of the ion association were calculated.

\section{Instrumentation}

\section{EXPERIMENITAL}

The UV absorption spectra were recorded on a PerkinElmer Lambda (25 UV-VIS) spectrophotometer in a quartz cuvette $(1.0 \mathrm{~cm}$ path length). Conductivity readings were taken with a Suntex, model SC- 170 conductivity meter.

\section{Chemicals}

All chemicals used were prepared using analytical grade chemicals and double-distilled water. Sarcosine (Sar, 98\%), threonine (The, 99.5\%), serine (Ser, 99\%), glutamate (Glu, 99\%), aspartate (Asp, 98\%), arginine (Arg, 99.5\%), methionine (Met, 99\%), Cysteine (Cys, 99\%), tryptophane (Try, 99\%) and phenylalanine (Phe, 99\%) were purchased from Fluka (Fig.-1), while copper nitrate hemi pentahydrate $\left[\mathrm{Cu}\left(\mathrm{NO}_{3}\right)_{2}, 5 \mathrm{H}_{2} \mathrm{O}\right]$ was purchased from Merck.<smiles>CNCC(=O)O</smiles>

Sarcosine $\left(\mathrm{D}_{1}\right)$<smiles>C[C@@H](O)[C@H](N)C(=O)O</smiles>

Threonine $\left(\mathrm{D}_{2}\right)$

Serine $\left(\mathrm{D}_{3}\right)$<smiles>N[C@@H](CC(=O)O)C(=O)O</smiles>

Aspartate $\left(\mathrm{D}_{5}\right)$<smiles>CC(C)(C)CC[C@H](N)C(=O)O</smiles><smiles>N[C@@H](CS)C(=O)O</smiles>

Cysteine $\left(\mathrm{D}_{8}\right)$<smiles>N[C@@H](Cc1c[nH]c2ccccc12)C(=O)O</smiles>

Tryptophane (D9)<smiles>N[C@@H](Cc1ccccc1)C(=O)O</smiles>

Phenylalanine $\left(\mathrm{D}_{10}\right)$

Fig.-1: Structures of Chemical Donors

\section{Preparation of standard solutions of the donors and acceptor}

All the solutions were based on $100 \mathrm{~cm}^{3}$ of water for the spectrophotometric measurements. Measurements of electronic spectra have been carried out in an aqueous solution of variable donor and acceptor at concentrations of $10^{-2}$ and $10^{-4}$ mole. $^{-1}$ between 190 and $1100 \mathrm{~nm}$. The wavelength maxima were characterized at a temperature of $298 \mathrm{~K}$.

For conductometric measurements, stock solutions of copper and different amino acids are initially prepared at concentrations of $10^{-1}$ mol..$^{-1}$ of the donor and the acceptor. For each step and each complex, $50 \mathrm{ml}$ of the desired solution is placed in a beaker that is adjusted to the corresponding value of the 
RASĀYAN J. Chem.

Vol. 14 | No. 3 |1573-1580| July - September | 2021

conductivity simultaneously the absorbance $(A B S)$ is measured. Then, the solution was half diluted. Again, $50 \mathrm{ml}$ of the taken solution conductivity and absorbance $(A B S)$ is measured. The operation is repeated until the conductivity of the solution reaches that of water $(\mathrm{pH}=7$ and the specific conductance of water was less than $\left.2-4,5 \mu \mathrm{S} . \mathrm{cm}^{-1}\right)$.

The proposed structure of metal complexation between heavy metal ion $\mathrm{Cu}$ (II) and Amino acid is presented in Fig.-2.

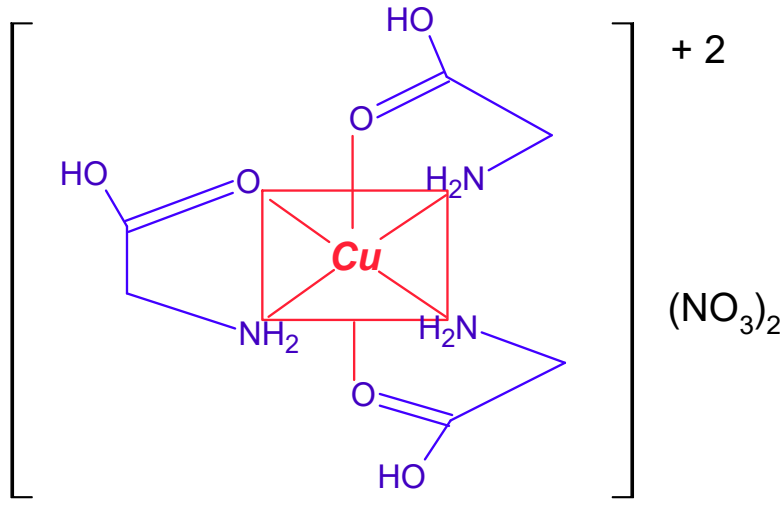

Fig.-2: Proposed Structure of the Complex

\section{Spectroscopic Study}

\section{RESULTS AND DISCUSSION}

The $\left(K^{A D}\right)$, and $\left(\varepsilon^{A D}\right)$ of each complex, were determined from UV-Vis spectra using both modified and non-modified Benesi-Hildebrand (Eq. (1) and-Eq. (2)).

$$
\begin{aligned}
& {\left[A_{0}\right] / A B S=1 /\left(K^{A D} \varepsilon^{A D}\left[D_{0}\right]\right)+\left(1 / \varepsilon^{A D}\right)} \\
& {\left[A_{0}\right] / A^{a}=1 /\left(K^{A D} \varepsilon^{a}\left[D_{0}\right]\right)+\left(1 / \varepsilon^{a}\right)}
\end{aligned}
$$

Where $\left[A_{0}\right]$ is the initial concentration of the acceptor and $\left[D_{0}\right]$ is the initial concentration of the donor. The following Equations used to calculate $A^{a}$ and $\varepsilon^{a}$ are mentioned in more details in the reference work by Benesi-Hildebrand. ${ }^{17}$

The ionization potential was calculated by using two methods by equations (3) and (4): ${ }^{14-21}$

$$
\begin{aligned}
& h v_{C T}=I^{D}-C_{1}+\left[C_{2} /\left(I^{D}-C_{1}\right)\right] \\
& h v_{C T}=a I^{D}+b \\
& I^{D}=4,39+0,857 h v_{C T} \\
& I^{D}=5,1+0,7 h v_{C T}
\end{aligned}
$$

$h v_{C T}$ : Absorption band energy of CT complex, and $h$ : Planck's constant, $C_{1}=5.2 \mathrm{eV}, C_{2}=1.5 \mathrm{eV}^{2}, a=$ 0.87 or $0.67, b=-3.6$ or -1.9 .

Where $h v_{C T}$ is the absorption band energy of the charge transfer complex in eV., $I^{D}$ is the ionization potential of the donor in $\mathrm{eV} . C_{1}, C_{2}, a$, and $b$ in Equations 5 and 6 are constants.

From complexes, $D_{1}$ to $D_{10}$ new absorption bands are shown in the visible region whose wavelengths are $760,710,760,740,760,665,750,750,710$, and $760 \mathrm{~nm}$, respectively. Whereas, the appearance of a band at $810 \mathrm{~nm}$ associated with the acceptor is reported (Table-1).

The values of $K^{A D}$ and $\boldsymbol{\varepsilon}^{A D}$ are determined by plotting a graph (Eq.-7):

$$
\left[A_{0}\right] / A=f\left(1 /\left[D_{0}\right]\right)
$$


RASĀYAN J. Chem.

Vol. 14 | No. 3 |1573-1580| July - September | 2021

Table-1: Charge-transfer Absorption Maxima of $\mathrm{Cu}$ (II) with Different Donors

\begin{tabular}{c|c|c}
\hline Donors & $\lambda_{\max }(\mathrm{nm})$ Complex & $(\Delta \lambda / \lambda) \cdot 10^{+5}$ \\
\hline Sarcosine $\left(\mathrm{D}_{1}\right)$ & 760 & 1,316 \\
\hline Threonine $\left(\mathrm{D}_{2}\right)$ & 710 & 1,408 \\
\hline Serine $\left(\mathrm{D}_{3}\right)$ & 760 & 1,316 \\
\hline Glutamate $\left(\mathrm{D}_{4}\right)$ & 740 & 1,351 \\
\hline Asparatate $\left(\mathrm{D}_{5}\right)$ & 760 & 1,316 \\
\hline Arginine $\left(\mathrm{D}_{6}\right)$ & 665 & 1,504 \\
\hline Methionine $\left(\mathrm{D}_{7}\right)$ & 750 & 1,333 \\
\hline Cysteine $\left(\mathrm{D}_{8}\right)$ & 750 & 1,333 \\
\hline Tryptophane $\left(\mathrm{D}_{9}\right)$ & 710 & 1,408 \\
\hline Phenylalanine $\left(\mathrm{D}_{10}\right)$ & 760 & 1,316 \\
\hline
\end{tabular}

In general, the variation of $\left[A_{0}\right] / A^{a}$ against $1 /\left[D_{0}\right]$ leads to a linear relationship. A rough estimation of $\boldsymbol{\varepsilon}^{\boldsymbol{A D}}$ and $K^{A D}$ of the complexes can be calculated and used for the nonlinear relationship. ${ }^{22}$ The estimated values of $K^{A D}$ and $\varepsilon^{A D}$ were obtained from the plots. ${ }^{23}$

The values of $K^{A D}$ and $\varepsilon^{A D}$ for all complexes are shown in Table-2. The corresponding plots are displayed in Fig.-3, with good correlation factors $\left(R^{2}>0,98\right)$.
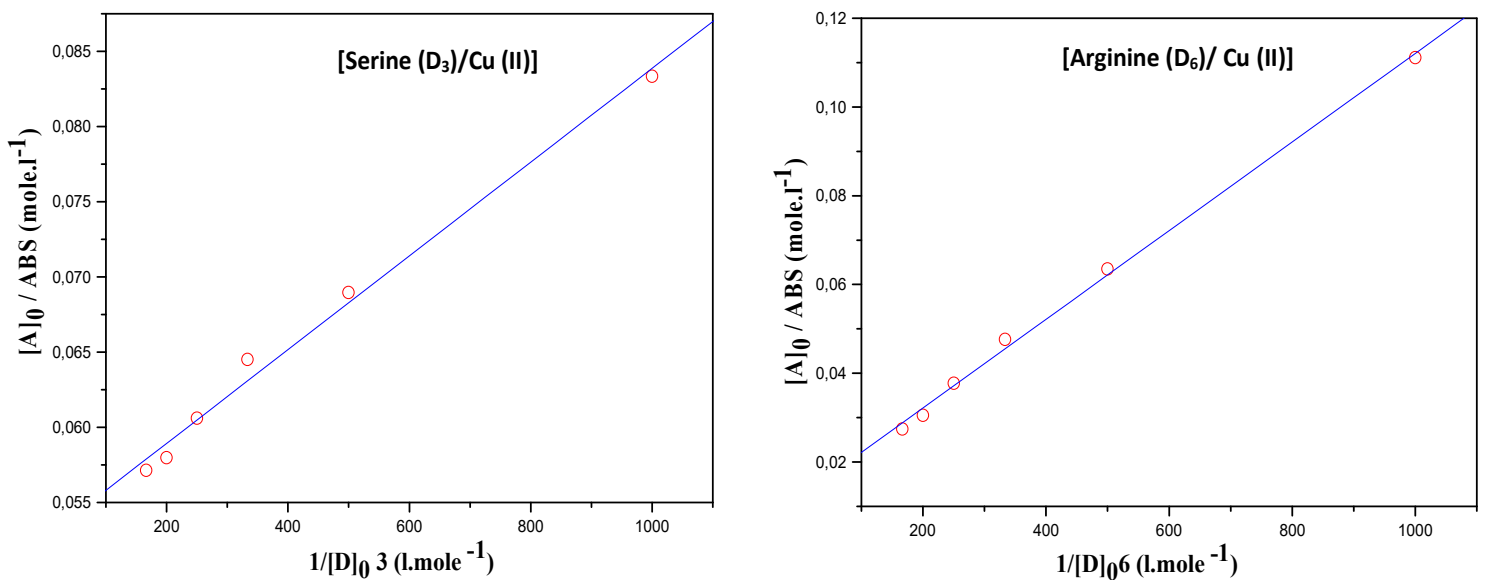

Fig.-3: Benesi-Hildebrand Plots of the Complexes $\mathrm{D}_{3}$ and $\mathrm{D}_{6}$ at $298 \mathrm{~K}$

Molar absorptivity's, $\varepsilon^{A D}$, obtained from Eqn.-1, are 18.886, 18.765, 18.997, 16.666, 19.948, 81.967, $20.738,19.782,18.663$, and $19.892 .1 . \mathrm{cm}^{-1} \mathrm{~mol}^{-1}$ for complexes $\mathrm{D}_{1}$ to $\mathrm{D}_{10}$, while the values of $K^{A D}$, are given in Table-2. These 2834, 1672, 1424, 2566, 122, 1380, 1650, 1020 and $1274\left(\mathrm{dm}^{3} \cdot \mathrm{mole}^{-1}\right)$ allow the establishment of the stability order for identical complexes as follows:

$\left[\mathrm{D}_{1} / \mathrm{Cu}(\mathrm{II})\right]>\left[\mathrm{D}_{5} / \mathrm{Cu}(\mathrm{II})\right]>\left[\mathrm{D}_{2} / \mathrm{Cu}(\mathrm{II})\right]>\left[\mathrm{D}_{8} / \mathrm{Cu}(\mathrm{II})\right]>\left[\mathrm{D}_{3} / \mathrm{Cu}(\mathrm{II})\right]>\left[\mathrm{D}_{4} / \mathrm{Cu}(\mathrm{II})\right]>\left[\mathrm{D}_{7} / \mathrm{Cu}(\mathrm{II})\right]>$ $\left[\mathrm{D}_{10} / \mathrm{Cu}(\mathrm{II})\right]>\left[\mathrm{D}_{9} / \mathrm{Cu}(\mathrm{II})\right]>\left[\mathrm{D}_{6} / \mathrm{Cu}(\mathrm{II})\right]$

Table-2: Association Constants and Molar Extinction Coefficient for each Complex.

\begin{tabular}{c|c|c}
\hline Donors & $K^{A D}\left(1 . \mathrm{mol}^{-1}\right)$ & $\varepsilon^{A D}\left(1 . \mathrm{cm}^{-1} \cdot \mathrm{mole}^{-1}\right)$ \\
\hline Sarcosine $\left(\mathrm{D}_{1}\right)$ & 2834 & 18.886 \\
\hline Threonine $\left(\mathrm{D}_{2}\right)$ & 1672 & 18.765 \\
\hline Serine $\left(\mathrm{D}_{3}\right)$ & 1590 & 18.997 \\
\hline Glutamate $\left(\mathrm{D}_{4}\right)$ & 1424 & 16.666 \\
\hline Asparatate $\left(\mathrm{D}_{5}\right)$ & 2566 & 19.948 \\
\hline Arginine $\left(\mathrm{D}_{6}\right)$ & 122 & 81.967 \\
\hline Methionine $\left(\mathrm{D}_{7}\right)$ & 1380 & 20.738 \\
\hline Cysteine $\left(\mathrm{D}_{8}\right)$ & 1650 & 19.782 \\
\hline Tryptophane $\left(\mathrm{D}_{9}\right)$ & 1020 & 18.663 \\
\hline Phenylalanine $\left(\mathrm{D}_{10}\right)$ & 1274 & 19.892 \\
\hline
\end{tabular}

1576 
RASĀYAN J. Chem.

Vol. 14 | No. 3 |1573-1580| July - September | 2021

The greater stability of the complex $\left[\mathrm{D}_{1} / \mathrm{Cu}\right.$ (II)] could be explained by the presence of the inductive effect of the methyl group donor. The same explanation can be given for the highest stability of the complex $\left[\mathrm{D}_{2} / \mathrm{Cu}\right.$ (II)] compared to the complex $\left[\mathrm{D}_{3} / \mathrm{Cu}\right.$ (II)]. Unlike the complex $\left[\mathrm{D}_{6} / \mathrm{Cu}\right.$ (II)], the inductive effect of withdrawing nitrogen atoms appears significantly diminishes the stability of the complex. As complex $\left[\mathrm{D}_{7} / \mathrm{Cu}\right.$ (II)] and $\left[\mathrm{D}_{8} / \mathrm{Cu}\right.$ (II)], the latter is less stable because of the important attracting inductive effect of $\mathrm{CH}_{3}-\mathrm{S}$ group compared to the group H-S. Regarding the complexes $\left[\mathrm{D}_{4} / \mathrm{Cu}\right.$ (II)] and $\left[\mathrm{D}_{5} / \mathrm{Cu}(\mathrm{II})\right]$, the distance coordination sites $\left[\mathrm{D}_{4} / \mathrm{Cu}\right.$ (II)] by its analog seem significantly decrease the stability of the complex. Furthermore, when comparing the stability of the complexes of aromatic amino acids, it is influenced not only by the electronic character of the methyl substituents but also by their steric effects: the complex $\left[\mathrm{D}_{10} / \mathrm{Cu}(\mathrm{II})\right]$ appears more stable than the complex $\left[\mathrm{D}_{9} / \mathrm{Cu}(\mathrm{II})\right]$ because of the flatness of the former.

The stability of the complexes of aliphatic amino acid compounds is greater than that of the aromatic amino acids due to the solvation of polar solvents (aqueous); water molecules prevent the copper ions approach the nucleus aromatic. It may be noted that the more complex charge transfer bandwidth, the higher the stability of the complex is great, and the electronic transfer phenomenon of the donor to the acceptor is complete. $\left[\mathrm{D}_{6} / \mathrm{Cu}\right.$ (II)] seems to be most sensitive to light in the visible. The presence of nitrogen atoms in this complex could be the cause of this sensitivity.

The absorption band energy, $E_{C T}$, was calculated by using Eq.-8:

$$
E_{C T}=h v_{\max }=h c / \lambda_{\max }
$$

Where $C$ is the speed of light in a vacuum, $\lambda_{\max }$ is the wavelength, and $h$ is the Planck constant.

The absorption band wavelengths and energy absorption band for each complex are shown in Table-3.

Table-3: Absorption Band Wavelengths, Energy Absorption Band for each Complex.

\begin{tabular}{c|c|c|c}
\hline Donors & $\lambda_{\max }(\mathrm{nm})$ & $E_{C T}(\mathrm{eV})$ & $\left(\Delta E_{C T} / E_{C T}\right) \cdot 10^{+5}$ \\
\hline Sarcosine $\left(\mathrm{D}_{1}\right)$ & 760 & 1,631 & 1,316 \\
\hline Threonine $\left(\mathrm{D}_{2}\right)$ & 710 & 1,746 & 1,408 \\
\hline Serine $\left(\mathrm{D}_{3}\right)$ & 760 & 1,631 & 1,316 \\
\hline Glutamate $\left(\mathrm{D}_{4}\right)$ & 740 & 1,675 & 1,351 \\
\hline Aspartate $\left(\mathrm{D}_{5}\right)$ & 760 & 1,631 & 1,316 \\
\hline Arginine $\left(\mathrm{D}_{6}\right)$ & 665 & 1,864 & 1,504 \\
\hline Methionine $\left(\mathrm{D}_{7}\right)$ & 750 & 1,653 & 1,333 \\
\hline Cysteine $\left(\mathrm{D}_{8}\right)$ & 750 & 1,653 & 1,333 \\
\hline Tryptophane $\left(\mathrm{D}_{9}\right)$ & 710 & 1,746 & 1,408 \\
\hline Phenylalanine $\left(\mathrm{D}_{10}\right)$ & 760 & 1,631 & 1,316 \\
\hline
\end{tabular}

The ionization Potential $I^{D}$ of the different amino acids, complexing Copper (II) determined by the eqns.3 to 6 when the variation of mean values of $I^{D}$ is ranging from 7,637 to 8,265 eV, as shown in Table-4..$^{24,25}$

Table-4: Ionization Potentials $I^{D}$ of the Various Amino Acid

\begin{tabular}{c|c|c|c|c|c}
\hline \multirow{2}{*}{ Donors } & \multicolumn{5}{|c}{$I^{D}(\mathrm{eV})$} \\
\cline { 2 - 6 } & Eqn.-3 & Eqn.-4 & Eqn.-5 & Eqn.-6 & Average Value \\
\hline Sarcosine $\left(\mathrm{D}_{1}\right)$ & 7,976 & 7,915 & 7,342 & 7,511 & 7,686 \\
\hline Threonine $\left(\mathrm{D}_{2}\right)$ & 8,805 & 8,539 & 7,818 & 7,900 & 8,265 \\
\hline Serine $\left(\mathrm{D}_{3}\right)$ & 7,976 & 7,915 & 7,342 & 7,511 & 7,686 \\
\hline Glutamate $\left(\mathrm{D}_{4}\right)$ & 8,278 & 8,142 & 7,515 & 7,653 & 7,897 \\
\hline Aspartate $\left(\mathrm{D}_{5}\right)$ & 7,976 & 7,915 & 7,342 & 7,511 & 7,686 \\
\hline Arginine $\left(\mathrm{D}_{6}\right)$ & 7,906 & 7,862 & 7,301 & 7,478 & 7,637 \\
\hline Methionine $\left(\mathrm{D}_{7}\right)$ & 8,123 & 8,025 & 7,426 & 7,580 & 7,788 \\
\hline Cysteine $\left(\mathrm{D}_{8}\right)$ & 8,123 & 8,025 & 7,426 & 7,580 & 7,788 \\
\hline Tryptophane $\left(\mathrm{D}_{9}\right)$ & 8,805 & 8,539 & 7,818 & 7,900 & 8,265 \\
\hline Phenylalanine $\left(\mathrm{D}_{10}\right)$ & 7,976 & 7,915 & 7,342 & 7,511 & 7,686 \\
\hline
\end{tabular}


RASĀYAN J. Chem.

Vol. 14 | No. 3 |1573-1580| July - September | 2021

\section{Conductometric Study}

The molar conductance $(\Lambda)$ for all studied complexes was evaluated by the following relation (Eq.-9):

$$
\Lambda=1000 \sigma / C
$$

Where $(\sigma)$ is the measured specific conductance in $(\mu \mathrm{S} / \mathrm{cm})$, and $C$ the molar concentration of the solution. The equivalent conductance $(\Lambda)$ for all studied systems was recorded in Table-5.

The use of the Kohlrausch equation showed experimentally that the equivalent conductivity for each concentration of amino acid at a given temperature was plotted against the square root of concentration $\mathrm{C}^{1 / 2}$ as shown in Fig.-4. The limiting value of the molar conductivity $\Lambda_{0}=\Lambda(\mathrm{C} \rightarrow 0 \mathrm{~mol} / \mathrm{l})$ was obtained by linear extrapolation of the $\Lambda\left(\mathrm{C}^{1 / 2}\right) .{ }^{26,27}$
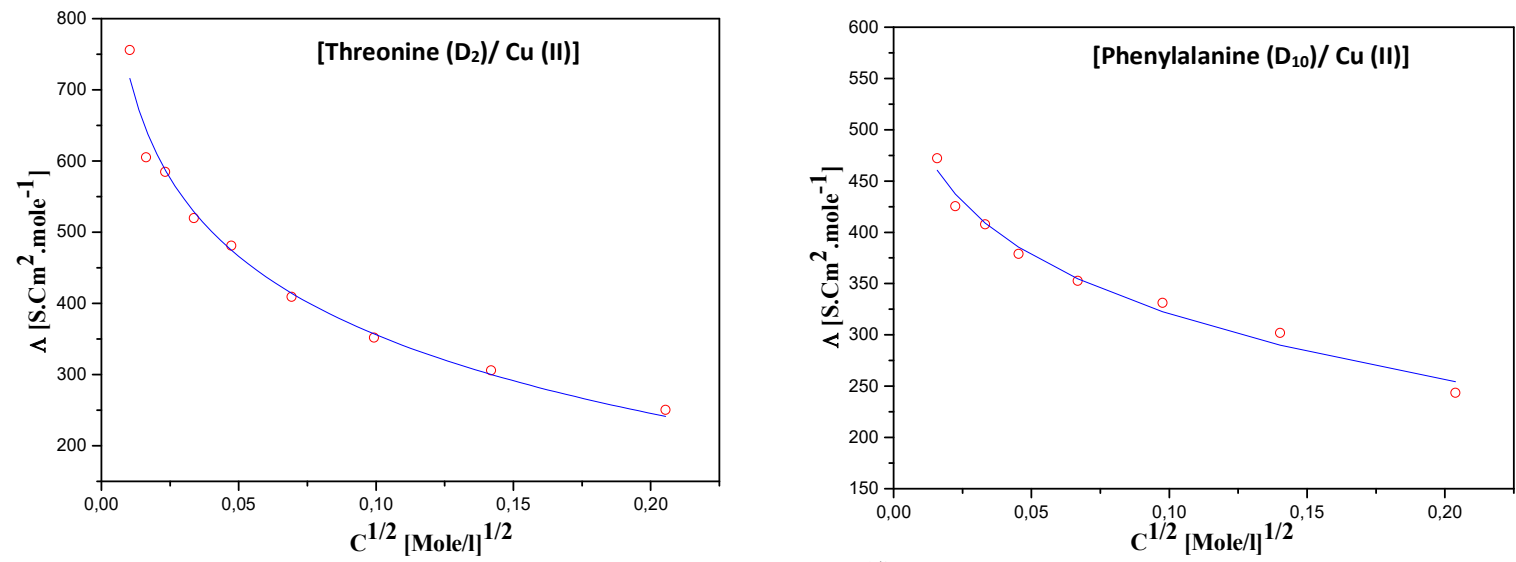

Fig.-4: Equivalent Conductance $(\Lambda)$ as a Function of $\mathrm{C}^{1 / 2}$ of the Complexes $\mathrm{D}_{2}$ and $\mathrm{D}_{10}$ at $298 \mathrm{~K}$

Arrhenius suggested that the degree of dissociation or ionization has can be calculated by the report Eq.10:

$$
\alpha=\Lambda / \Lambda_{0}
$$

The absorbance of each complex is measured to the maximal wavelength characterizing $\left(\lambda_{\max }\right)$ it. From the degree of dissociation, $\alpha$, of weak electrolyte, one can calculate the constant of dissociation, $K a$, of this electrolyte by the report Eq.-11:

$$
K_{a}=\left(\alpha^{2} . C\right) /(1-\alpha)
$$

The thermodynamic quantities as calculated, from the Benesi-Hildebrand plot, are shown in Table-5. Knowing the values of $K a$, the values of standard Gibbs energy $\Delta G^{0}$, entropy $\Delta S^{0}$, and enthalpy $\Delta H^{0}$ for each [Amino acid / $\mathrm{Cu}$ (II)] interaction were evaluated using the following thermodynamics eqns.-12 and 13.

$$
\begin{aligned}
& \Delta G^{\circ}=-R T \operatorname{Ln} K^{A D} \\
& \Delta H^{\circ}=\Delta G^{\circ}+T \Delta S^{\circ}
\end{aligned}
$$

$\mathrm{R}$ is the ideal gas constant.

The enthalpy $\Delta H^{0}$ was illustrated by the Vant-Hoff equation (Eq.-14) in the temperature range from (298$314 \mathrm{~K}) .^{28}$

$$
\text { Ln } K^{A D}=-\left(\Delta H^{\circ} / R T\right)+c
$$

As shown in Table-5 the enthalpy of association $\left(\Delta H^{\circ}\right)$ of the complexes negative which means that the formation of the metal complexes occurs via exothermic hydration. ${ }^{29}$

Moreover, a variation of $\Delta G^{\circ}$ values is noted from the $\mathrm{D}_{1}$ to $\mathrm{D}_{10}$ complexes formation reactions corresponding to $K^{A D}$ such, -12,038, -17,354, -17,912, -18,112, -18,191, -18,467, -18,560, -18,593, 19,666 and $-19,915 \mathrm{KJ}$. mole ${ }^{-1}$. The negative value of standard Gibbs energy $\Delta G^{0}$ for the complexes suggests a spontaneous nature of such processes. ${ }^{30}$ The spontaneity of these reactions follows the trend: $\left[\mathrm{D}_{6} / \mathrm{Cu}(\mathrm{II})\right]>\left[\mathrm{D}_{9} / \mathrm{Cu}(\mathrm{II})\right]>\left[\mathrm{D}_{10} / \mathrm{Cu}(\mathrm{II})\right]>\left[\mathrm{D}_{7} / \mathrm{Cu}(\mathrm{II})\right]>\left[\mathrm{D}_{4} / \mathrm{Cu}(\mathrm{II})\right]>\left[\mathrm{D}_{3} / \mathrm{Cu}(\mathrm{II})\right]>\left[\mathrm{D}_{8} / \mathrm{Cu}(\mathrm{II})\right]>\left[\mathrm{D}_{2}\right.$ $/ \mathrm{Cu}(\mathrm{II})]>\left[\mathrm{D}_{5} / \mathrm{Cu}(\mathrm{II})\right]>\left[\mathrm{D}_{1} / \mathrm{Cu}(\mathrm{II})\right]$ 
RASĀYAN J. Chem.

Vol. 14 | No. 3 |1573-1580| July - September | 2021

The values of entropy $\Delta S^{0}$ were also negative due to the negative values of enthalpy $\Delta H^{0}$. This is due to contributions from both the formation of ion pairs and the ordering of the system because of association under the influence of solvation and columbic effect in spontaneous continuum media.

Table-5: Conductance and Thermodynamics Parameters for the Complexes $\Lambda\left(\mathrm{S}_{\mathrm{Cm}} \mathrm{Cm}^{2} \cdot \mathrm{mol}^{-1}\right)$

\begin{tabular}{c|c|c|c|c|c|c|c|c|c|c}
\hline $\mathrm{C}(\mathrm{mol} / \mathrm{l})$ & {$\left[\mathrm{D}_{1} / \mathrm{Cu}\right]$} & {$\left[\mathrm{D}_{2} / \mathrm{Cu}\right]$} & {$\left[\mathrm{D}_{3} / \mathrm{Cu}\right]$} & {$\left[\mathrm{D}_{4} / \mathrm{Cu}\right]$} & {$\left[\mathrm{D}_{5} / \mathrm{Cu}\right]$} & {$\left[\mathrm{D}_{6} / \mathrm{Cu}\right]$} & {$\left[\mathrm{D}_{7} / \mathrm{Cu}\right]$} & {$\left[\mathrm{D}_{8} / \mathrm{Cu}\right]$} & {$\left[\mathrm{D}_{9} / \mathrm{Cu}\right]$} & {$\left[\mathrm{D}_{10} / \mathrm{Cu}\right]$} \\
\hline 0,10000 & 194,192 & 250,437 & 224,006 & 207,062 & 194,192 & 263,009 & 94,2000 & 174,054 & 207,142 & 243,566 \\
\hline 0,05000 & 230,974 & 305,801 & 254,801 & 216,171 & 230,974 & 283,159 & 113,200 & 203,445 & 251,434 & 301,921 \\
\hline 0,02500 & 259,884 & 351,971 & 288,960 & 268,187 & 259,884 & 296,362 & 129,720 & 227,645 & 279,899 & 331,147 \\
\hline 0,01250 & 302,186 & 409,077 & 339,571 & 301,284 & 302,186 & 311,475 & 140,080 & 272,199 & 311,304 & 352,727 \\
\hline 0,00625 & 316,679 & 481,188 & 382,790 & 361,493 & 316,679 & 383,222 & 152,160 & 312,256 & 325,126 & 378,887 \\
\hline 0,00312 & 314,752 & 519,782 & 402,059 & 409,217 & 314,752 & 407,424 & 160,960 & 311,06 & 336,173 & 407,725 \\
\hline 0,00156 & 404,611 & 584,502 & 453,005 & 456,087 & 404,611 & 451,843 & 167,104 & 350,123 & 356,609 & 425,415 \\
\hline 0,00078 & 454,882 & 604,984 & 537,298 & 625,392 & 454,882 & 754,096 & 180,864 & 367,806 & 380,667 & 472,084 \\
\hline$\Lambda_{0}(\mathrm{~S} . \mathrm{Cm} / \mathrm{mol})$ & 645.085 & 800,215 & 599,338 & 638.751 & 650,046 & 799,244 & 225,245 & 550,125 & 501,245 & 520,123 \\
\hline $\mathrm{Ka}(1 / \mathrm{mol})$ & 2834 & 1672 & 1590 & 1424 & 2568 & 122 & 1380 & 1650 & 1020 & 1274 \\
\hline$\Delta \mathrm{G}^{\circ}(\mathrm{KJ} / \mathrm{mol})$ & $-18,593$ & $-18,467$ & $-18,467$ & $-18,191$ & $-19,666$ & $-12,038$ & $-18,112$ & $-18,561$ & $-17,354$ & -17.912 \\
\hline$\Delta \mathrm{H}^{\circ}(\mathrm{KJ} / \mathrm{mol})$ & $-38,451$ & $-38,451$ & $-37,758$ & $-37,102$ & $-39,568$ & 35,012 & $-36,235$ & $-37,254$ & $-35,758$ & $-36,122$ \\
\hline$\Delta \mathrm{S}^{\circ}(\mathrm{J} / \mathrm{mol} \mathrm{K})$ & $-63,461$ & $-63,461$ & $-66,782$ & $-63,460$ & $-66,782$ & -87.154 & $-60,815$ & $-62,731$ & 61,758 & $-61,107$ \\
\hline
\end{tabular}

\section{CONCLUSION}

The spectrophotometric analysis confirmed that complexes are formed in the solution so which is endorsed by the Benesi-Hildebrand equation. The thermodynamic study allowed us to calculate the variation of the enthalpy $\Delta H$ and that of the enthalpy $\Delta S$ of the formation and rearrangement of ion pairs to elucidate the different ion-solvent interactions for our systems; The negative value of the standard Gibbs energy $\Delta G^{0}$ for the complexes suggests the spontaneous nature of such processes and confirmed more stability of the complex.

\section{REFERENCES}

1. S. Kobayashi, K. Hiroishi, M. Tokunoh and T. Saegusa, Macromolecules, 20(7), 1496(1987), https://doi.org/10.1021/ma00173a009

2. P. Canzares, A. Pérez and R. Camarillo, Desalination, 144(1-3), 279(2002), https://doi.org/10.1016/S0011-9164(02)00328-4

3. N. Kamal, S. Ahzi and V. Kochkodan, Applied Clay Science, 199, 105873(2020), https://doi.org/10.1016/j.clay.2020.105873

4. J. Labanda, M.S. Khaidar and J. Llorens, Desalination, 249(2), 577(2009), https://doi.org/10.1016/j.desal.2008.06.031

5. S. Racharla, B.J. Kumar and G. Kiran, Rasayan Journal of Chemistry, 12(1), 64(2019), https://doi.org/10.31788/RJC.2019.1215014

6. L. Kiss, I. M. Mándity, and F. Fülöp, Amino Acids, 49(9), 1441(2017), https://doi.org/10.1007/s00726-017-2439-9

7. R. Ramesh, P.K. Suganthy and K. Natarajan, Synthesis and Reactivity in Inorganic and MetalOrganic Chemistry, 26(1), 47(1996), https://doi.org/10.1080/00945719608004245

8. R.A. Siddiqui, P. Raj, A.K. Saxena and S.K. Dixit, Synthesis and Reactivity in Inorganic and MetalOrganic Chemistry, 26(7), 1189(1996), https://doi.org/10.1080/00945719608004361

9. Y. Ohashi, Bulletin of the Chemical Society of Japan, 70(6), 1319(1997), https://doi.org/10.1246/bcsj.70.1319

10. A.H. Al-Taiar, S.K. Shubber and A. Megherbi, Turkish Journal of Chemistry, 26, 351(2002). 
RASĀYAN J. Chem.

Vol. 14 | No. 3 |1573-1580| July - September | 2021

11. A.H. Al-Taiar, M.A. Al-Ekabe, F.A. Al-Mashadane and M. Hadjel, Journal of Coordination Chemistry, 55(10), 1143(2002), https://doi.org/10.1080/0095897021000022230

12. S.H. Hastings, J.L. Franklin, C. Schiller and F.A. Matsen, Journal of the American Chemical Society, 75(12), 2900(1953), https://doi.org/10.1021/ja01108a033

13. H. McConnell, J.S. Ham and J.R. Platt, The Journal of Chemical Physics, 21(1), 66(1953), https://doi.org/10.1063/1.1698626

14. R.S. Mulliken and W.B. Person, Annual Review of Physical Chemistry, 13(1), 107(1962), https://doi.org/10.1146/annurev.pc.13.100162.000543

15. F.A. Matsen, The Journal of Chemical Physics, 24(3), 602(1956), https://doi.org/10.1063/1.1742553

16. H. Kuroda, Nature, 201(4925), 1214(1964), https://doi.org/10.1038/2011214a0

17. H.A. Benesi and J.H. Hildebrand, Journal of the American Chemical Society, 71(8), 2703(1949), https://doi.org/10.1021/ja01176a030

18. R. Foster and I. Horman, Journal of the Chemical Society B, 0(0), 1049(1966), https://doi.org/10.1039/J29660000171

19. F.M. Menger and M.L. Bender, Journal of the American Chemical Society, 88(1), 131(1966), https://doi.org/10.1021/ja00953a025

20. I.M. Khan, S. Shakya, M. Islam, S, Khan and H. Najnin, Physics and Chemistry of Liquids, 1(2020), https://doi.org/10.1080/00319104.2020.1810250

21. P. Morlaës and J.C. Morlaës, Cinétique Chimique, Vuibert, St-Germain, France, p. 166-168(1949)

22. G. Sarova, M.-N. Berberan-Santos, The Journal of Physical Chemistry B, 108(44), 17261(2004), https://doi.org/10.1021/jp047019z

23. H. Yada, J. Tanaka and S. Nagakura, Bulletin of the Chemical Society of Japan, 33(12), 1660(1960), https://doi.org/10.1246/bcsj.33.1660

24. K.R. Bhaskar, S.N. Bhat, A.S.N. Murthy and C.N.R. Rao, Transactions of the Faraday Society, 62(0), 788(1966), https://doi.org/10.1039/TF9666200788

25. R.S. Mulliken, Journal de Chimie Physique, 61, 20(1964), https://doi.org/10.1051/jcp/1964610020

26. P.W. Atkins, Physical Chemistry, Oxford University Press, UK, p.1171(1992), https://doi.org/10.1002/bbpc.19900941026

27. K. N. Semenov, N. A. Charykov, I. V. Murin and Y. V. Pukharenko, Journal of Molecular Liquids, 202, 1(2015), https://doi.org/10.1016/j.molliq.2014.12.002

28. A.R. Nixha, H. Demirhan and M. Arslan, Rasayan Journal of Chemistry, 10(4), 1374(2017), https://doi.org/10.7324/RJC.2017.1041883

29. M.Y. AL-Tamer, Ph.D. Thesis, Mosul University, Iraq, p. 62, (1999).

30. K.D. Bhesaniya and D. Baluja, Journal of Molecular Liquids, 190, 190(2014), https://doi.org/10.1016/j.molliq.2013.11.015

[RJC-6402/2020] 